books. The principles and methods of inventory-making are presented first, and the selection of materials is arranged by century from the 16th to 20th century. Each map or picture is shown in facsimile with its call number and description. At the end, there is a list of the maps, graphics and atlases by author, title and call number (chronological order) also arranged by century, a list of the facsimiles, a list of the books, and finally an alphabetical index of authors, call number abbreviations and proper names.
The Novak Collection has so far been presented in part to the Croatian and international public by Dr. Drago Novak, and through scientific and expert articles by his associates at scientific conferences and meetings. However, this is the first publication in which a comprehensive analysis and full depiction of the historical-social context of the Collection is presented, processed and catalogued. Since the Novak Collection is one of only a very few, truly significant, valuable Croatian cartographic collections, this project is very important in order to preserve and affirm it, and is also of great importance to Croatian national cultural and scientific heritage. The authors are renowned experts and scientists in the area of the history of cartography and are also curators of the Novak Collection, and have dealt with the material in a thoroughly professional way, analysing and describing it. This book is a huge undertaking in the preservation of cultural heritage and undoubtedly of enormous significance to Croatian science and culture.

\title{
Digital Terrain Modelling
}

\section{Ante Šiljeg, Mirko Barada, Ivan Marić}

The book Digital Terrain Modelling by Ante Šiljeg, Mirko Barada and Ivan Marić was created as synthesis of Dr. Ante Šiljeg's PhD thesis titled DEM in the Analysis of Geomorphometric Parameters: Example of Vransko Lake Nature Park written at the Faculty of Science, Department of Geography, University of Zagreb, and the diploma thesis by Mirko Barada, Master of Geography titled The Impact of User-defined Parameters on the Accuracy of the EDM published at the Department of Geography, University of Zadar. The book was published by ALFA d.d., Zagreb and University of Zadar, the editor is Marko Labus. The book published in 2018 contains 264 pages with 181 pictures and 53 tables. The book is written in Croatian, B5 format, it is hardbound and is marked by ISBN 978-953-297-857-5. It was reviewed by Prof. Dr. Mirko Borisov, Prof. Dr. Mladen Jurišić, Assist. Prof. Dr. Gojko Nikolić, Prof. Dr. Snježana Musa and Prof. Dr. Sanja Lozić.

Due to the complexity of the topic, the content is divided into nine chapters:
1. Introduction

2. Summary of Previous Research

3. Digital Terrain Modelling Theoretical Framework

4. User Practices in the Process of Digital Terrain Modelling

5. Practical Examples of DEM Creation from Different Altitude Data Sets

6. The Concept of Pixel-size Improvement of Photogrammetric Data

7. Accuracy Estimation of Pixel Heights

8. DEM Accuracy in Hydrologic Parameter Modelling

9. Digital Terrain Analysis

The book ends with a list of sources, references, graphic supplements and tables, as well as a table of contents and acknowledgements.

The book examines the impact of user-defined parameters on the accuracy of the digital elevation model (DEM). The entire process of digital terrain modelling is presented with special emphasis on the significance of interpolation and spatial resolution.

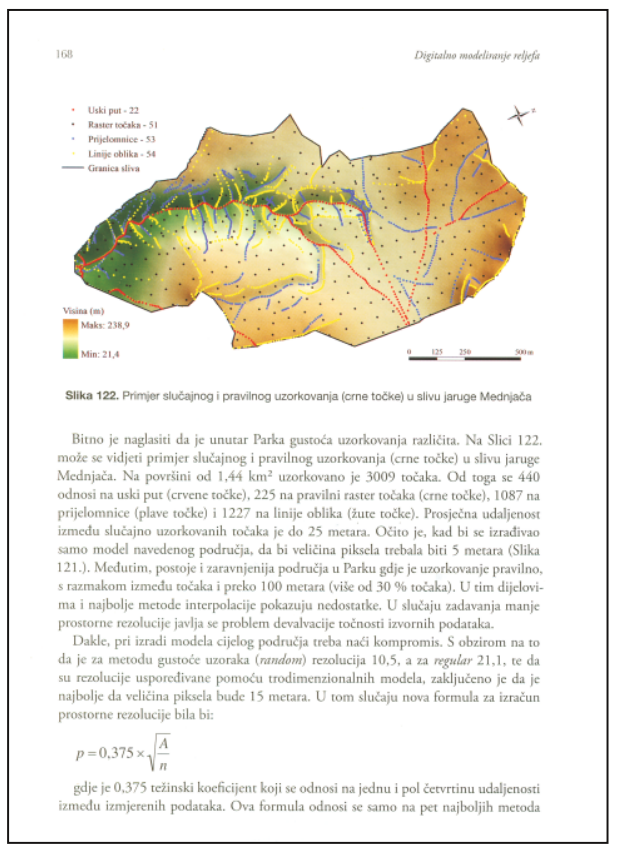

In the third chapter, Digital Terrain Modelling - The Theoretical Framework, the theoretical basis is given and various phases of digital terrain modelling are interpreted. Special emphasis is put on three basic user-defined parameters, i.e. methods of collecting altitude data, spatial 
naslova knjiga. Na početku su prikazana primijenjena načela i metoda inventarizacije, a izbor građe je podijeljen po stoljećima, od 16. do 20. stoljeća. Prikaz svake odabrane karte i grafike u Katalogu sastoji se od faksimila (snimke), signature i opisa. $\mathrm{Na}$ kraju se nalazi Popis karata, grafika i atlasa prema autoru, nazivu i signaturi (kronološki slijed), također po stoljećima, Popis faksimila, Popis knjiga te na kraju Abecedni popis autora i oznaka kratica signatura i Kazalo osobnih imena.
Zbirku Novak dosada su djelomice predstavljali hrvatskoj i međunarodnoj javnosti njezin autor dr. Drago Novak, ali i njegovih suradnici na znanstvenim skupovima i sastancima i kroz znanstvene i stručne tekstove. Međutim, tako cjelovita analiza i cjeloviti povijesno-društveni kontekst Zbirke Novak, te njezina obrada i katalogizacija po prvi je puta objavljena. Kako je Zbirka Novak jedna od malobrojnih i jedna od doista najvažnijih i najbogatijih hrvatskih kartografskih zbirki, tako da je ovaj projekt od iznimnog značenja za njezino očuvanje i njezinu afirmaciju, ali također i za hrvatsku nacionalnu kulturnu i znanstvenu baštinu. Afirmirane stručnjakinje i znanstvenice iz područja povijesti kartografije, kustosice Zbirke Novak, besprijekorno su stručno i Zbirku znalački obradile, analizirale i opisale, tako da je ta knjiga veliki pothvat u očuvanju baštine te ima neosporno iznimno značenje za hrvatsku znanost i kulturu.

Borna Fuerst-Bjeliš

\section{Digitalno modeliranje reljefa}

\section{Ante Šiljeg, Mirko Barada, Ivan Marić}

Knjiga Digitalno modeliranje reljefa Ante Šiljega, Mirka Barade i Ivana Marića nastala je kao sinteza doktorskog rada autora dr. sc. Ante Šiljega pod naslovom DMR $u$ analizi geomorfometrijskih parametara: primjer PP Vransko jezero, koji je izrađen na Geografskom odsjeku Prirodoslovnomatematičkog fakulteta Sveučilišta u Zagrebu i diplomskog rada autora Mirka Barade, mag. geogr. pod naslovom Utjecaj korisničko-definiranih parametara na točnost DMR-a objavljenog na Odjelu za geografiju Sveučilišta u Zadru. Nakladnici su ALFA d.d., Zagreb i Sveučilište u Zadru, urednik je Marko Labus, a objavljena je 2018. godine na 264 stranice sa 181 slikom i 53 tablice. Knjiga je na hrvatskom jeziku, formata B5, tvrdo je ukoričena i nosi oznaku ISBN 978-953-297-857-5. Recenzenti su bili izv. prof. dr. sc. Mirko Borisov, prof. dr. sc. Mladen Jurišić, doc. dr. sc. Gojko Nikolić, prof. dr. sc. Snježana Musa i izv. prof. dr. sc. Sanja Lozić.

Zbog kompleksnosti problematike, sadržaj je strukturno razgranat u ovih devet poglavlja:
1. Uvod

2. Pregled dosadašnjih istraživanja

3. Digitalno modeliranje reljefa teorijska osnova

4. Prakse korisnika u procesu digitalnog modeliranja reljefa

5. Praktični primjeri izrade DMRova iz različitih skupova visinskih podataka

6. Koncept poboljšavanja veličine piksela fotogrametrijski prikupljenih podataka

7. Ocjena točnosti visina u pikselu

8. Točnost DMR-a u modeliranju hidroloških parametara

9. Digitalne analize reljefa.

Knjiga završava s popisom izvora, literature, grafičkih priloga i tablica te sadržajem i zahvalama.

U knjizi se istražuje utjecaj korisničko-definiranih parametara na točnost digitalnog modela reljefa (DMR). Prikazan je cjelokupan proces digitalnog modeliranja reljefa s posebnim naglaskom na važnost metoda interpolacije i prostorne rezolucije.

U trećem poglavlju Digitalno modeliranje reljefa - teorijska osnova tumače se različite faze digitalnog

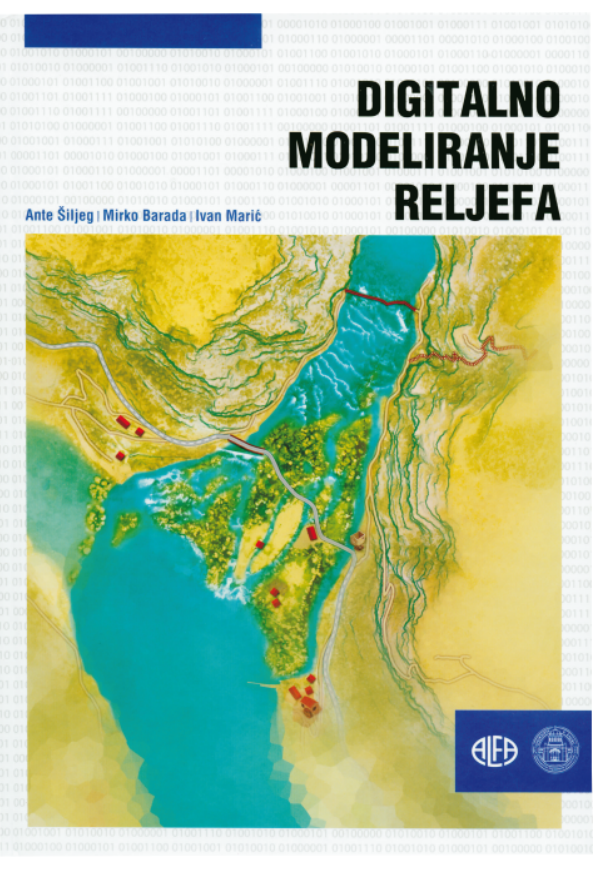

modeliranja reljefa. Poseban naglasak dan je na tri osnovna korisničko-definirana parametra, tj. na metodama prikupljanja visinskih podataka, metodama prostorne interpolacije i metodama određivanja prikladne veličine piksela, odnosno određivanju prostorne rezolucije. Nakon opisa 
interpolation methods and methods of determining suitable pixel size or spatial resolution. The description of theoretically available digital terrain models is followed by the theoretical basis for interpretation of accuracy, i.e. DEM quality and precision.

The fourth chapter of the book features the first presentation of the results of a survey of users from around the world on their practices in terms of determination user-defined parameters in the process of digital terrain modelling and the related evaluation aspects of the digital elevation model accuracy.

The theoretical basis described in the third and fourth chapter of the book is applied in practice to data that show the area of the Vransko Lake Nature Park. Thus, the fifth chapter describes the procedure of creating DEMs from various altitude data sets obtained through different methods, techniques and procedures (bathymetric measurements, vectorization of contour lines from Croatian Base Map, and aerial photogrammetry stereo-restitution analysis). The most suitable interpolators for the purposes of various studies were chosen by comparing nine deterministic and eight geostatistical interpolation methods. Furthermore, using five methods, the spatial resolution was calculated to find the most suitable one to describe and present relief of the research area in the most appropriate way.

The concept of improving the spatial resolution of a model obtained from data collected by photogrammetric methods is suggested and their visual accuracy is given in the sixth chapter. Created models are also evaluated using different statistical parameters. The concept of hybrid DEM is also developed. The external and internal evaluation of the resulting models' accuracy is conducted in the seventh chapter. The eighth chapter describes DEM accuracy in modelling hydrological parameters, while a digital relief analysis according to geomorphologic and morphometric parameters is carried out in the ninth chapter.

The subject of the book is very popular abroad, while few studies on it have been published in Croatia. Therefore, because of theoretically elaborated subject followed by practical examples, this book is intended for students, scientists and teachers in the higher education of geography, geodesy and geoinformatics. It can also be applied in other scopes such as civil engineering, agriculture, forestry, ecology, geology, hydrology, i.e. in all fields in which relief is of great importance and needs to be evaluated.

Martina Triplat Horvat

\title{
Archaeological Map of the Island of Pag
}

\author{
Ivo Oštarić, Anamarija Kurilić
}

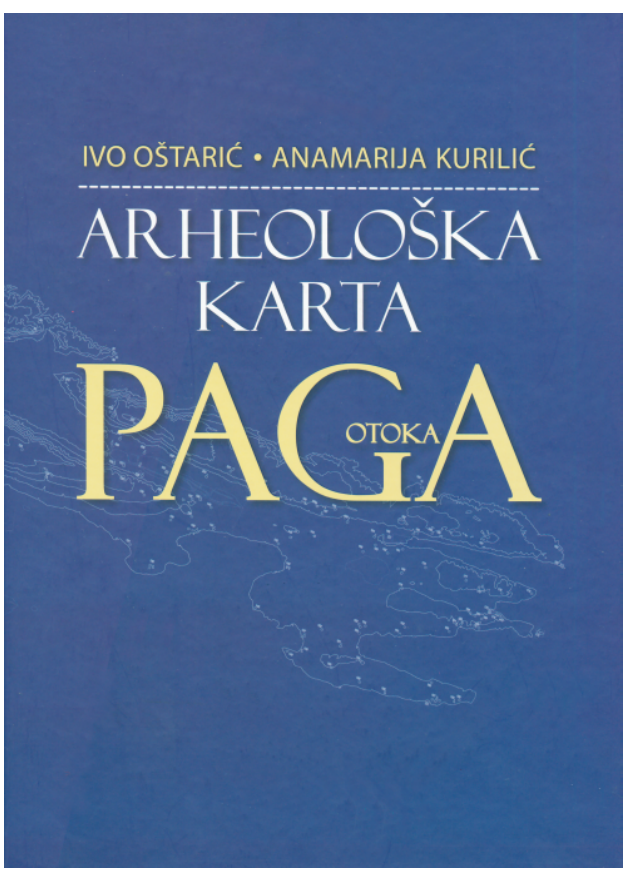

The Novalja branch of Matrix Croatica (Matica hrvatska) and the city of Novalja published the monography Archaeological Map of the Island of Pag by MSc. Ivo Oštarić and Dr. Anamarija Kurilić in 2003. The monography was edited by Aleksij Škunca and reviewed by Prof. Dr. Zdenko Brusić and Prof. Dr. Slobodan Čače. The monography is written in Croatian, containing 335 pages with 403 pictures, size $27 \times 20.5$ $\mathrm{cm}$, it is hardbound and is marked by ISBN 978-953-99844-1-8.

The monograph includes a simple general map in an in unknown scale which indicates archaeological sites, namely prehistoric settlements and graves, Roman remains, as well as late antique and medieval churches beyond larger settlements. The map indicates churches of the city of Pag, Pag Old City and the city of Novalja with a single symbol, since it was difficult to map them clearly because of their numbers and limited space. Signature sites are divided into 12 categories. The map was prepared by MSc. Ivo Oštarić, and made by Dr. Kristijan Juran.

The monography is structured in the following chapters:

1. Foreword

2. Introduction

3. Prehistoric Period

4. Antique and Late Antique Period

5. Middle Ages.

The monography ends with a list of references, list of sites according to number, alphabet, periods, types and reviews. 
teorijski dostupnih digitalnih modela reljefa dana je teorijska osnova tumačenju točnosti, odnosno kvaliteti i preciznosti DMR-a.

U četvrtom su poglavlju knjige po prvi puta predstavljeni rezultati anketnog ispitivanja korisnika iz cijelog svijeta o njihovim praksama pri određivanju korisničko-definiranih parametara $u$ procesu digitalnog modeliranja reljefa i s njima povezanim aspektima evaluacije točnosti digitalnih modela reljefa.

Teorijska osnova, opisana u trećem i četvrtom poglavlju knjige, praktično je primijenjena na podacima koji prikazuju područje Parka prirode Vransko jezero. Tako je u petom poglavlju opisan postupak izrade DMR-ova iz različitih skupova visinskih podataka koji su dobiveni različitim metodama, tehnikama i procedurama prikupljanja (batimetrijskom izmjerom, vektorizacijom izohipsi s Hrvatske osnovne karte, zračnim laserskim snimanjem te aerofotogrametrijskom izmjerom i stereorestitucijskom obradom). Usporedbom devet determinističkih i osam geostatističkih metoda interpolacije, odabrani su najprikladniji interpolatori za potrebe različitih istraživanja. Nadalje, prostorna rezolucija izračunana je s pomoću pet metoda kako bi se pronašla najprikladnija s kojom bi se na najadekvatniji način opisao i prikazao reljef istraživanog područja.

U šestom poglavlju, predložen je koncept poboljšavanja prostorne rezolucije modela dobivenih iz podataka prikupljenim fotogrametrijskim metodama i dana njihova vizualna ocjena točnosti. Izrađeni modeli vrednovani su različitim statističkim parametrima. Također je razvijen koncept hibridnog DMR-a. U sedmom poglavlju knjige provedena je eksterna i interna evaluacija točnosti dobivenih modela. O točnosti DMR-a u modeliranju hidroloških parametara pisano je u osmom poglavlju knjige, dok su u devetom poglavlju provedene digitalne analize reljefa uz pomoć geomorfoloških i morfometrijskih parametara.

Tematika ove knjige veoma je popularna u inozemstvu, međutim objavljenih istraživanja koji ju obrađuju na hrvatskom jeziku je malo. Stoga je ova knjiga, zbog teorijski obrađene teme koju prati praktična primjena, sadržajem namijenjena studentima, znanstvenicima i nastavnicima $u$ visokom školstvu geografije, geodezije i geoinformatike. Knjiga može biti primjenjiva i u drugim područjima poput građevinarstva, poljoprivrede, šumarstva, ekologije, geologije, hidrologije, odnosno u svim područjima u kojima reljef ima veliku važnost pa ga je potrebno vrednovati.

Martina Triplat Horvat

\title{
Arheološka karta otoka Paga
}

\author{
Ivo Oštarić, Anamarija Kurilić
}

Ogranak Matice hrvatske u Novalji i grad Novalja objavili su 2013. godine monografiju Arheološka karta otoka Paga autora mr. sc. Ive Oštarića i dr. sc. Anamarije Kurilić. Urednik monografije je Aleksij Škunca, a recenzenti su bili prof. dr. Zdenko Brusić i prof. dr. Slobodan Čače. Monografija je na hrvatskom jeziku, sastoji se od 335 stranica sa 403 ilustracije, dimenzija $27 \times 20,5 \mathrm{~cm}$, tvrdo je ukoričena i nosi oznaku ISBN 978-953-99844-1-8.

Uz monografiju priložena je jednostavna pregledna karta, izrađena u nepoznatom mjerilu, na kojoj su signaturama označeni položaji arheoloških nalazišta i to prapovijesnih naselja i grobova, rimskih ostataka te kasnoantičkih i srednjovjekovnih crkava izvan većih naselja. Crkve grada
Paga, paškoga Staroga Grada i grada Novalje na karti su prikazane jednom oznakom jer ih je bilo teško pregledno kartirati zbog njihove mnogobrojnosti i ograničenog prostora. Signature nalazišta podijeljene su u 12 kategorija. Kartu je pripremio mr. sc. Ivo Oštarić, a izradio doc. dr. sc. Kristijan Juran.

Sadržaj monografije strukturiran je u sljedeća poglavlja:

1. Predgovor

2. Uvod

3. Prapovijesno razdoblje

4. Antičko i kasnoantičko razdoblje

5. Srednji vijek.

Monografija završava s popisom literature, popisom nalazišta po rednim brojevima, po abecedi, razdobljima i prema vrsti te recenzijama.

\section{Iz recenzija:}

Živimo u vremenu intenzivnog prevrednovanja prostora, uz stalno nove gradnje i pregradnje koje nezibježivo ugrožavaju spomeničku baštinu, a ponajprije onu najmanje uočljivu, dakle arheološku. Ovaj rad pruža neophodnu podlogu za izradu iscrpnog "katastra" baštine, dokumentacije koja bi bila na prikladan način dokumentirana i zaštićena; ujedno bi se osiguralo njeno istraživanje i odgovarajuća prezentacija. 